\title{
Implementation of the Concept of Birrul Walidaini in Conseling of Family
}

\author{
Afdal Afdal ${ }^{1}$, Taufik Taufik ${ }^{2}$, Ifdil Ifdil ${ }^{3 *}$ \\ ${ }^{123}$ Guidance \& Counseling Department, Faculty of Education, Universitas Negeri Padang, 25132, Padang, Indonesia *
}

\begin{abstract}
Students are the responsibility of teachers and parents in fulfilling their needs. It is not uncommon for students who have problems in school that require parents to come to school to solve problems. One form of eradicating student problems by providing family counseling services with the concept of Birrul Walidaini to parents of students. In this case, the family plays an important role in students 'behavior in school so that students' problems are resolved and return to living an effective life everyday. The method used is individual counseling interviews with samples single subject. After applying the concept of Birrul Walidaini and changing the negative perceptions of the client's parents, making the client can change in a positive direction.
\end{abstract}

\section{Keywords}

Birrul walidaini; Family counseling

Article Received: 20 September 2020, Revised: 30 November 2020, Accepted: 18 December 2020

\section{Introduction}

Various cases that occur in students in school, is none other than the frequent students not entering the class and going out during class hours are ongoing [1, 2]. Starting from the case of a high school grader in City X. Clients are potential students. A single child in his family, comes from a harmonious family. The fact that recently happened, clients often do not enter the class, even though from home the client always goes to school, but the client arrives at school when he or she disappears not in class. This incident dizzy the teacher, homeroom teacher, picket teacher, and BK teacher. Various approaches have been taken by BK teachers, conducting individual counseling, making agreements, including calling parents, all of these actions have not produced results, the client still does not enter the class.

Various approaches and theories can be applied to help students overcome personal problems [3]. Individual counseling is the primary choice for counseling modalities, followed by group counseling, and finally family counseling [4, 5]. In this case the school does not only serve students but also students' families, schools must recognize the impact and the family system on student behavior in school and that many problems of students in schools are related to family dysfunction [6]. Family counseling helps clients to alleviate the problems that they naturally experience [7], by applying approaches in counseling, making clients return to life effectively everyday [8]. Counseling techniques by applying Birrul Walidaini. Part in Islamic ethics that shows filial piety $[9,10]$, every Muslim must obey every command of both parents that does not conflict with the religion or command of Allah SWT. Birrul Walidain is the most important form of friendship. The pleasure of Allah depends on the pleasure of the parents and the wrath of God depends on the wrath of the parents (HR Tirmizi and Tabrani). Birrul's education is one of the most important factors in the ideal education of character, in the Qur'an many related verses about Birrul Walidain. One of them is the letter Luqman verse 14 and the letter Al-Isra verses 2324. Friman Allah in the two letters that a child with both parents must speak noble words, be a tawadhu, and pray for parents either alive or dead [11].

In a family usually consists of husband, wife and children [12], even in families in the community not infrequently other family members live together. For example grandfather, grandmother, uncle, cousin and so on. Among the family members there must be attitudes of mutual respect and respect [13-15] which among others are good words of speech, fun and beneficial actions [16].

In the interaction of children and parents, for example, every child must realize that both parents are the most meritorious people. Therefore, children must respect and respect both 
parents and in-laws. The in-laws are also both parents if they already have a husband, so treat them with respect and respect.

If you have a husband then as a form of obedience to the husband when talking about parents then also remember the parents-in-law, do good also to the in-laws who have raised and educated the husband, to become righteous children. It is appropriate to have a good relationship with him, treat as parents because by doing so it will foster harmony in the household itself and please the husband. As the hadith from Abu Hurairoh rodhiyallahu'anhu, he said: Ever asked Rosulullahi sholallahu'alaihi wasalam, "Who is the best woman?" He replied, "that is the most pleasing if seen by her husband, obeying her husband if he is ordered, and not over husband on himself and his property so as to make her husband hate "(HRAn-Nasai no.3231 an Ahma 2: 251. Shaykh Al Albani states that this hadith hasan is valid).

\section{Materials and Methods}

Data collection by using in-depth interviews on individual counseling and observation with asample single subject. Data collected from individual counseling interviews and observations were analyzed descriptively.

The next approach is to approach family counseling, counselors try to dialogue with parents of clients. Family counseling is used more often by individual counseling [17]. Family counseling abroad can improve family competitiveness, improve students' bad behavior and help in their healing process $[17,18]$. In addition, family counseling must focus on how to deal with children with disabilities, special needs, and smart ones. Therefore family counseling is offered actively in all places such as schools, hospitals, community centers. Stinchfield conducted a study of how family counseling is done at home and has a positive impact on family harmony [19]. Family counseling is useful in dealing with increased problems of a family member or more that affect children's problems, anger or depression from parents [17]. According to the parents of clients, that they are a religious family, praying together, clients are only children, raised with affection.
The next step, the counselor tried to reveal the relationship between parents and their parents. It was revealed that this family relationship with their parents was very good and even this family cared for their parents, and stayed at home with them [20].

The next step, the counselor tries to reveal how the parents of the client relate to his parents-inlaw. This is where it is revealed that parents have negative views on their parents-in-law. Client's parents perceive that their parents-in-law often ask for money and always undermine her husband. From here the counselor sees something that needs to be improved from this family, which is how to change negative perceptions of their inlaws. Even though the in-laws in the concept of Islamic religion are their parents too. Counselors suspect that parents' negative perceptions of their parents-in-law can be a cause of problems experienced by clients now, in the religion of Islam there is the concept of Birrul Walaidaini, which is doing good to parents, blessings of Allah lies in the blessings of both parents. maybe this is a reprimand from the Almighty, so their children have problems not wanting to go to school.

The next step the counselor tried to discuss the concept of Birrul Walidaini. Client's parents assume that Birrul Walidaini only applies to their parents, not included with their parents-in-law. Even though the concept of Birrul Walidaini, namely, doing good to the parents also included doing good to the parents-in-law (husband's parents).।

The next step is how the counselor strategies to change the parents' perceptions of their parents-inlaw. It is possible that the problems experienced by clients are caused by God's reprimand to parents of clients who have negative perceptions of their parents-in-law.

The next step is to change the parents' perceptions of the client, the counselor uses Adler's approach, which argues that human behavior is determined by its perception. Subjective perceptions of individuals shape behavior and personality [21]. Changing negative perception to positive $[22,23]$. 
After a change in perceptions of the client's parents, the client's parents have considered their parents-in-law as biological parents, and no longer have negative thoughts on their parents-in-law. And feel that helping in-laws is an obligation [24]. The client's parents also apologized, and asked his father-in-law to join in praying for his grandson to study again diligently, and be successful in the world and the hereafter. Not a long time later there was a change in the client, began to enter class and relearn with his friends.

\section{Conclusion}

After applying various approaches in counseling applied in handling client cases above such as individual counseling, with various techniques, home visits, finally family counseling is done by applying the concept of Birrul Walidaini, and changing the negative perceptions of the client's parents, so that eventually the client can change to positive direction.

\section{Acknowledgements}

We are very grateful to experts for their appropriate and constructive suggestions to improve this template.

\section{References}

[1] K. T. Aritonang, "Minat dan motivasi dalam meningkatkan hasil belajar siswa," Jurnal pendidikan penabur, vol. 7, pp. 11-21, 2008.

[2] T. Kartini, "Penggunaan metode role playing untuk meningkatkan minat siswa dalam pembelajaran pengetahuan sosial di kelas V SDN Cileunyi I Kecamatan Cileunyi Kabupaten Bandung," Jurnal Pendidikan Dasar, vol. 8, pp. 16-17, 2007.

[3] S. Syahniar, "The application of impact counseling in therapy started with individual counseling expressive to cope with the personal problems by college students," COUNS-EDU: The International Journal of Counseling and Education, vol. 2, pp. 6369, 2017.

[4] d. M. G. Kurang, "Asuhan keperawatan keluarga," 2008.

[5] J. Z. Taylor and S. Kashubeck-West, "Counseling Preferences of Young Adults with Cancer," Professional Counselor, vol. 7, pp. 259-271, 2017.
[6] M. S. Snyder, Teachers' perceptions of students' needs for family counseling and attitudes toward school-based family counseling: Capella University, 2010.

[7] K. J. Desmond and A. Kindsvatter, "Intentional practices in supervision of family counseling: The use of supervisory letters," The Family Journal, vol. 18, pp. 3135, 2010.

[8] A. Fatih, Tantangan Pendidikan Islam di Era Globalisasi, 2004.

[9] A. R. Mutia and M. Ali, "Dinamika Sistem Pendidikan SMP Birrul Walidain Muhammadiyah Sragen," Universitas Muhammadiyah Surakarta, 2018.

[10] I. R. B. Shaari, "Konsep Pembinaan Birrul Walidain dalam Al-Qur'an (Kajian Analisis Deskriptif Tafsir Maudhu'i)," UIN ArRaniry Banda Aceh, 2017.

[11] F. P. Nufus, et al., "Konsep Pendidikan Birrul Walidain dalam QS. Luqman (31): 14 dan QS. Al â€"isra (17): 23-24," Jurnal Ilmiah Didaktika: Media Ilmiah Pendidikan dan Pengajaran, vol. 18, pp. 16-31, 2017.

[12] H. Gunawan, "Jenis pola komunikasi orang tua dengan anak perokok aktif di Desa Jembayan Kecamatan Loa Kulu Kabupaten Kutai Kartanegara," Ejournal Ilmu Komunikasi, vol. 1, pp. 218-233, 2013.

[13] A. Larasati, "Kepuasan perkawinan pada istri ditinjau dari keterlibatan suami dalam menghadapi tuntutan ekonomi dan pembagian peran dalam rumah tangga," Jurnal Psikologi Pendidikan dan Perkembangan, vol. 1, pp. 1-6, 2012.

[14] W. Sudarta, "Peranan wanita dalam pembangunan berwawasan gender," Fakultas Pertanian Universitas Udayana, 2007.

[15] A. B. Utama, "Pembentukan Karakter Anak Melalui Aktivitas BermainDalam Pendidikan Jasmani," Jurnal pendidikan jasmani indonesia, vol. 8, 2011.

[16] M. Ikhwan, "Peningkatan Prilaku Birrul Walidain pada Pembelajaran Aqidah Akhlaq Melalui Metode Sosiodrama Siswa Kelas III MI Negeri Buduran Kabupaten Sidoarjo," UIN Sunan Ampel Surabaya, 2014.

[17] N. M. Noor, "Family Counseling in Malaysia: Current Issues and Practices," International Education Studies, vol. 7, pp. 
33-39, 2014.

[18] A. Milliren and C. Barrett-Kruse, "Four phases of Adlerian counseling: Family resilience in action," Journal of Individual Psychology, vol. 58, pp. 225-234, 2002.

[19] R. Stinchfield and K. C. Winters. (2004). Adolescents and Young Adults. Available: psycnet.apa.org

[20] J. Hartati, et al., "Hubungan antara Perlakuan Orangtua dengan Penerimaan Diri Siswa," Konselor, vol. 2, 2013.

[21] A. Nurcahya and O. P. Mulyana, "Perbedaan Efikasi Politik Ditinjau dari Tipe Kepribadian Introversi dan Ekstraversi Pada Dewan Perwakilan Mahasiswa," Jurnal Psikologi Teori dan Terapan, vol. 7, pp. 76-81, 2017.

[22] S. F. Fitroh, "Hubungan antara kematangan emosi dan hardiness dengan penyesuaian diri menantu perempuan yang tinggal di rumah ibu mertua," Psikoislamika: Jurnal Psikologi dan Psikologi Islam, vol. 8, 2011.

[23] A. Sutriani, "Dinamika Relasi Menantu dengan Mertua yang Tinggal Serumah," Universitas Islam Negeri Sultan Syarif Kasim Riau, 2015.

[24] N. Rossalia and M. A. G. Priadi, "Conflict Management Style pada Pasangan Suami Istri yang Tinggal Bersama Mertua," Manasa-old, vol. 7, pp. 35-50, 2018. 